\title{
Pääkirjoitus
}

Jenni Mäenpää

\section{Tutkijan luovuutta pitää vaalia}

Helsingin yliopiston Tiedekulmassa järjestettiin syyskuun 2021 alussa keskustelutilaisuus otsikolla "Is the university a business?". Tilaisuuden taustalla oli huomioita nykypäivän yliopistojen niukkenevista resursseista, yliopistoyhteisön ja -hallinnon välisen luottamuksen ja vuoropuhelun puutteesta, työhuoneiden korvaamisesta monitilatoimistoilla ja ennen kaikkea siitä, että yritysmaailman toimintatavat ovat saaneet yliopistoissa yhä enemmän jalansijaa. Virkistävää tilaisuudessa oli, että siellä puhuttiin vaihteeksi tiedeyhteisön arvoista, yliopistodemokratiasta ja mainittiinpa myös tutkimuksen itseisarvo.

Yksi näistä arvoista on vapaus, joka on tärkeä paitsi tieteen riippumattomuuden turvaamiseksi myös siksi, että vapaus on edellytys luovuudelle. Luovuus taas on avainsana, kun mietitään lähes mitä tahansa tutkimuksen tekemisen vaihetta. Tutkimusidean keksiminen on luova prosessi, jossa parhaat ideat syntyvät silloin, kun asioita onnistutaan ajattelemaan jollain tavalla totutusta poikkeavista näkökulmista. Mahdollisimman kiinnostavan tutkimusasetelman ja -kysymysten keksiminen on niin ikään paras lähtökohta kiinnostaville tutkimustuloksille. Analyysi ja tulkintojen tekeminen vaativat erityistä luovuutta, kun uudet havainnot asetetaan vuoropuheluun aikaisemman tutkimuksen kanssa. Parhaimmillaan tässä risteyksessä syntyy uusia oivalluksia, jotka vievät eteenpäin jotain ideaa, teoriaa tai mallia. Ja sitten on tietysti itse kirjoittaminen, joka on luovaa työtä alusta loppuun.

Luovuustutkijat ovat luovuuden synnystä ja toimintaperiaatteista jossain määrin eri linjoilla. Eniten ristiriitaa erityisesti psykologiassa ovat aiheuttaneet kysymykset, onko luova prosessi kokonaan tietoista toimintaa ja voiko luovuuden moniulotteista ilmiökenttää alistaa mitattavaan muotoon. Luovasta prosessista tieteessä kirjoittanut kasvatustieteilijä ja filosofi Juha T. Hakala (2002) on lähestynyt ongelmaa keräämällä reflektioita luovuudesta tieteen nobelisteilta. Hakalan huomio oli, että tieteentekijöiden tavasta hahmottaa luovaa prosessia löytyy yhteneväisyyksiä. Ensinnäkin luovan prosessin lähtökohdaksi tarvitaan ongelma, jota on motivoiduttu ratkaisemaan ja jonka parissa työskennellään intensiivisesti muun muassa lukemalla aikaisempaa tutkimusta. Kun ongelma ei ajatustyöstä huolimatta ratkea, seuraa jonkinlainen herpaantuminen ja ongelman siirtäminen enemmän taka-alalle. Tämä hellittäminen on ratkaiseva kohta, sillä rentoutuneessa tilassa voi syntyä keskeinen oivallus. Oivallus syntyy usein tavanomaisuudesta poikkeavassa tilanteessa, silloin kun ongelman kanssa ei olla aktiivisesti tekemi- 
sissä. Kaiken kaikkiaan tyypillisiä luovassa prosessissa ovat vaihtelevat tunteet, epämääräisyys, sekavuus ja haparointi. Oivalluksen jälkeen haparointi ja epämääräisyys väistyvät, ja asiat tuntuvat asettuvan järjestykseen, mistä puolestaan seuraa tavallisesti vapautumisen tunne. Yleensä vaikean ongelman ratkaisemiseen tarvitaan useita oivalluksia, joiden syntymiseen voi kulua paljon aikaa. (Emt., 181-185.)

Edellä mainitut haparoinnille ja oivalluksille tarvittava aika ja rentoutunut tila ovat kuitenkin yliopistomaailmassa yhä useammin toteutumattomia ideaaleja, minkä takia tutkijan työssä onkin paljon ristiriitaisuutta luovuuden näkökulmasta. Ristiriita liittyy Tiedekulman tilaisuudenkin taustalla olevaan huoleen yliopistomaailman kasvavasta kilpailuhenkisyydestä, jonka seurauksena erityisesti julkaisemisen ja rahoituksen hakemisen paineet uuvuttavat monia tutkijoita. Esimerkiksi äärimmäisen kilpaillussa EU-tutkimusrahoituksessa peräänkuulutetaan erinomaisuutta ja uraauurtavuutta. Halutaan niin sanottuja suuren riskin ja suurten tuottojen (high risk - high gain) tutkimusideoita, jotka ovat sekä uusia että välttämättömiä toteuttaa (novelty). Vaikka rahoitettava tutkimus olisikin niin sanotusti vapaata verrattuna hyötynäkökulmiin kytkettyyn tutkimusrahoitukseen, silti tällaiset vaatimukset kalskahtavat yritysmaailmalta ja tuottavat painetta olla luova. Tämä on paradoksaalista, sillä luovuus ei viihdy liian paineisessa ympäristössä.

Tässä ajassa tutkijan luovuudesta onkin pidettävä erityistä huolta. Asiaa ei ratkaista yksilötasolla, mutta jokainen voi silti tehdä jotain oman luovuutensa hyväksi. Yksi asia, jonka on tutkitusti todettu edistävän luovuutta, on kävely. Stanfordin yliopiston psykologian ja kasvatustieteen tutkijat tekivät koeasetelman, jossa laitettiin ryhmä ihmisiä kävelemään ja keksimään sen jälkeen mahdollisimman monta käyttötarkoitusta annetuille esineille, minkä lisäksi kokeessa mitattiin korkeamman tason oivalluskykyä (Oppezzo ja Schwartz 2014). Verrokkiryhmä istui paikoillaan sisällä ja teki istumisen jälkeen saman divergenttiä ajattelua mittaavan kokeen. Tutkimuksen tulos oli, että kävely edisti merkittävästi erilaisten luovien ratkaisujen keksimistä. Suuria eroja ei puolestaan ollut siinä, kävelikö henkilö sisällä, ulkona vai juoksumatolla. Kävelyn vaikutukset säilyivät myös kävelemisen jälkeen. Tutkimuksen tulos puhuu esimerkiksi kävelykokouksien hyödyllisyyden sekä sen puolesta, että kävelemiselle kannattaa raivata työpäivästä aikaa.

Lisäksi aivotutkijat ovat viime aikoina kertoneet siitä, miten nykyinen työpäivien silppuisuus, jatkuvat keskeytykset, monen asian yhtäaikainen tekeminen ja älypuhelimen koukuttavat algoritmit heikentävät keskittymiskykyämme (Huotilainen ja Moisala 2018). Keskittymiskyky puolestaan on oleellista luovalle ajattelulle. Kirjassaan "Keskittymiskyvyn elvytysopas" Minna Huotilainen ja Mona Moisala esittävät keskittymisen parantamiseen monia samoja asioita, joita opetamme lapsillemme, mutta jotka meidän pitäisi opetella myös itse: riittävä uni, liikunta, laadukas ravinto, lepotauot ja älylaitteiden viisas käyttö.

Erityisesti työelämään liittyen kirjassa ehdotetaan uutta "työaikalakia". Siinä vuorokausi on jaettu kuuteen neljän tunnin jaksoon. Päivä alkaa virtausjaksolla, jossa on tarkoitus työskennellä keskittyneesti päivän tärkeimpien asioiden parissa niin, että nettiselain ja puhelin ovat kiinni. Tätä seuraa silpputyöjakso, jolloin vastataan sähköposteihin ja hoidetaan juoksevia asioita. Varsinainen työpäivä loppuu silppujaksoon, jota seuraa empatiajakso. Sen tarkoitus on varata aikaa läheisille ihmisille. Illalla ennen levon ja palautumisen jaksoja on rauhoittumisjakso, jonka aikana tehdään rauhallisia, tylsiä ja hidastempoisia asioita, jotka auttavat rentoutumaan. Jaksojen tarkoitus on auttaa keskit- 
tymään päivän aikana oleellisiin asioihin niin, ettemme poukkoilisi asiasta toiseen ja päivään jäisi riittävästi aikaa rauhoittumiselle. Tämä parantaa luovuutta ja ennaltaehkäisee työuupumusta. (Emt., 70-82.) Tutkimukset antavatkin selkeän viestin, jonka perusteella yliopistoyhteisön kannattaisi paitsi kävellä myös ennen kaikkea pyrkiä minimoimaan kilpailullisuudesta aiheutuvia paineita ja luomaan tutkijoille pitkäjänteisen keskittymisen edellytyksiä.

\section{Kirjallisuus}

Hakala, Juha T. 2002. Luova prosessi tieteessä. Helsinki: Gaudeamus.

Huotilainen, Minna ja Mona Moisala. 2018. Keskittymiskyvyn elvytysopas. Jyväskylä: Tuuma-kustannus.

Oppezzo, Marily ja Daniel L. Schwartz. 2014. "Give Your Ideas Some Legs: The Positive Effect of Walking on Creative Thinking." Journal of Experimental Psychology: Learning, Memory, and Cognition (40) 4: 1142-1152. https://doi.org/10.1037/a0036577. 